\title{
Shelf Life and Acceptability of Different Fruity Flavored Soy milk under two Types of Storage Method
}

\author{
Prof. Glena L. Caluza \\ Mindanao State University \\ Main Campus, Marawi City, Lanao Del Sur
}

\begin{abstract}
Soymilk or Soya milk is liquid obtained by suspending soybean flour in water, used as a fat-free substitute for milk, particularly by vegans and by those unable to tolerate milk products. Soy milk is a good substitute for cow's milk on many levels. It acts as a good source of protein, lactose-free, an interesting alternative for consumers who are lactose intolerant and allergic to cow's milk. Nowadays, many food products are enhanced, engineered, modified and fortified for health and economic reasons. The aimed of this study was to evaluate the sensory aspects and shelf life of fruit flavored soy milk using two different storage method and consumers' acceptability. To this goal, there were five different powdered fruits were added in appropriate amount to the plain soy milk like mango, soursop, melon, strawberry and banana. The shelf life of the products was tested between two storage methods. The results interestingly manifested that in average shelf life under refrigerated condition, the melon flavored soymilk had the longest shelf life of 24 days, soursop flavored with 21 days, banana had 20 days, strawberry had 15 days and mango flavored was the shortest shelf life of 10 days. Unrefrigerated samples majority revealed that it only lasts for 10 hours. For sensory evaluation and acceptability, there were 105 trained and consumer typed of pane lists involved in actual food testing based on Hedonic Scale Acceptability Test. The overall acceptability revealed that strawberry flavor soymilk was ranked as like moderately by the consumers as well as banana and melon. Unflavored soymilk, mango and soursop are slightly acceptable. The overall result of product acceptability constituted as good. The interpretation of the findings signified that adding fruit flavor to pure soya milk enhance its palatability factor and mask the beany-off flavor and consequently offer more variance of soya milk product to choose from and also it is economically feasible.
\end{abstract}

Keywords: flavored soy milk, shelf life, storage method, acceptability, profitability.

\section{Introduction}

Through the years, there has been a gap between population growth and food production. This gap continues to increase to the extent that malnourishment has become prevalent in the country. It is because population growth is known to be faster than the speed of food production. Although efforts are expended towards increasing agricultural productivity, all these may simply go to waste if agricultural yield will not be harnessed fully (Gatchalian, 1986). Thus, there is an imperative to provide the means to increase food availability. One of the answers to this need is proper practice of food processing such as milk alternative both at the farm site, and in the food manufacturing sectors.

In many developing countries where malnutrition is a major problem, legumes and nuts have been tapped as alternative protein sources. The most common of these protein sources are soybeans, peanuts and mungbeans. (De Leon Sonia Y., Claudio, Virginia S. et. al., 1999). Soybean (Glycine max L.) is an important plant protein source, a potential source of bioactive peptides and contains high level of mineral and amino-acids (Hayta et. al; 2003). In the Philippines, soybean is called "utaw" by some. The Filipino people have long known some important soybean preparations such as soy sauce or "toyo", bean curd or "tokwa" and fermented bean curd "tausi" (Ancheta, 1987).

Among the many soy products, soymilk is one of the popular traditional products in China and other Asian countries 
(Shun-Tang et. al., 1997) consumed as a nutritious and economical protein food (Matsuura et al.., 1989). Food consumers particularly in western countries prefer soymilk as a suggestive substitute in animals' milk due to lactose intolerance or aversely reaction to animals' milk specifically cow's milk, and as a cheap source of high quality protein and energy (Rosenthal et. al. 2003; Lui, 1997; Kwok and Niranjan, 1995; Kanthamani et. al., 1978).

Soymilk is one of the most popular soybean products, with plain and vanilla being most common flavors, although these beverages are being developed in a wide variety of other flavors (Chambers et. al., 2006). Soymilk and soymilk beverages consumption provides well-known health benefits (Hasler, C.M. 1998) and can also be an interesting alternative for consumers who are lactose intolerant, allergic to milk, avoid milk for any other reason (Reilly at. al., 2006).

Processing of soybeans into products are simple; farming families in soybean producing barangays could easily learn the simple technologies of soybean utilization. If this is achieved, then nutritious soybean products or food stuffs could be made available for the farm families as part of their daily food source. With all these important food substances present in the soybean, it is highly recommended as one of the best economical food crops of our farm families who are working hard daily and need nutritious food.

Meanwhile, soybean milk has a natural beany-off flavor, which is not popular for some consumers. The fruity flavored soymilk is made to provide greater varieties of soybean milk, and more nutritional and acceptable values for consumers. Fruit flavors soymilk is an upgraded product using soybean as main ingredient. This is low-cost but healthy food and has great benefit to human health. Besides, this strives to provide decent job for future effort to develop innovative processing strategies for producing and processing soybean product for food industry. This will help alleviate the malnutrition situation, being a good source of family income.

It is observed that one of the serious problems facing the country today particularly in some rural community is malnutrition due to poverty condition, specifically known as rural poor. The malnourished condition is a result of lack of income in that they cannot provide the basic nutrients stated in the three basic food groups and in the food pyramid, namely carbohydrates, protein, fats, vitamins and minerals. The most common deficiency in the diet is protein wherein good sources are meat and leguminous products.

The shelf life of soymilk is of great consideration to make the product acceptable and safe for human consumption. Shelf life is influenced by mean factors, such as heating and preparation method, its packaging and how the milk alternatives are being stored to lengthen the storability factor and to reach the final consumers with utmost quality.

To help provide good source of protein among the growing children in the rural families, this study was conducted to develop a soybean-based beverage. Specifically, this aims to evaluate the sensory aspects and the acceptability attributes of soymilk beverage with different fruit flavors such as mango, soursop, melon, strawberry and banana to enhance its sensory characteristic and to establish the desirable storability or shelf life with different storage methods. Also the study assesses the economic feasibility of the product and promotes soymilk as the best milk alternative and excellent source of protein from plants for rural families.

\section{Experimental Design}

A two-factorial experiment using Completely Randomized Design (CRD) was employed in the study in a controlled laboratory environment with two factors and replicated three times.

\section{Soybean Variety and Fruit Flavors Used}

Soybean variety IPB-Sy 96-27-23 was used. It has light yellow color, starchy, food grade soybean, ideal for soymilk processing. Powdered fruits are manufactured by MJ Commodity Flavors and Spices Inc. S.M.R. DFAD LTO \# RDII-RIV-F-2977. 


\section{Treatment Used}

Treatment are as follows:

1) Factor A- Storage methods

A1- Room Temperature or unrefrigerated, and

A2- Refrigerated

2) Factor B-Fruity flavored soymilk

B1-Unflavored soymilk

B2-Soymilk +Mango

B3-Soymilk +Soursop

B4- Soymilk +Melon

B5-Soymilk +Strawberry

B6- Soymilk +Banana

The Ingredients of flavored Soymilk

1 kilogram soybean seed

.667 kilogram refined sugar

20 grams rock salt

80 grams fruit flavorings

12 liters drinking water

The Procedures in Making Flavored Soymilk

1. All necessary materials were prepared;

2. The soybean seeds were cleaned and sorted out, the defected seeds, pebbles and other foreign materials were removed;

3. The soybean seeds were washed with clean tap water;

4. The soybeans were soaked overnight for 8 hours, after soaking, the water was drained;

5. The cleaned soybean seeds were quickly steamed for easier removal of its seed coat;

6. The soybean seed coat was eliminated by rubbing using hands with flowing tap water. The beans were ready for milk extraction;

7. Cleaned soybean seeds were blended for five minutes or until smooth. One kilogram of soybean seeds, twelve liters of drinking water was added. The soymilk was strained into a casserole through a very fine sieve and re-strain using double-layered cheesecloth to ensure the separation of the okara from the milk;

8. The soymilk was boiled to $90{ }^{\circ} \mathrm{C}$ centigrade for 15 minutes, stirred occasionally to prevent scorching;

9. The soymilk was removed from heat and cooled with running water, when the temperature dropped to $50{ }^{\circ} \mathrm{C}$, melted powdered fruits were gradually added;

10. Cooled flavored soya milk was packed in the transparent bottle and sealed tightly;

11. Packed soymilk was stored under two storage methods as used in the study. 


\section{- Preparation of Materials}

- Sorting and Cleaning

\section{- Washing}

- Soaking

\section{- Quick steaming}

- Removing of soybean seed coat

- Blending

- Boiling

\section{- Adding flavor and cooling}

\section{- Packing}

\section{- Storing}

\section{Experimental Procedure}

Soymilk was developed into another product by adding flavors in a desirable amount and right procedures to achieve the acceptable sensory characteristics. A total of ten kilograms was processed for the purpose of sensory evaluation and acceptability test as well as shelf life testing. Five kilograms of soybean was processed for sensory evaluation and acceptability test and another five kilograms was processed separately for shelf life testing. Mango flavored soymilk contained light yellow color; soursop flavor had a whitish color; melon flavored soymilk possessed light orange color; strawberry flavored soymilk was pinkish; and banana flavored soymilk contained off-white color.

Shelf life testing was conducted inside the laboratory room. Five kilogram of soybean was processed and it yielded 60 liters of soymilk. However, little amount of soymilk was lost through evaporation during boiling process. Six treatments were prepared: treatment (1) was unflavored soymilk; treatment (2) was soymilk with mango; treatment (3) was soymilk with soursop; treatment (4) was soymilk with melon; treatment (6) was soymilk with banana flavored. The six treatments were replicated thrice and each replication had ten samples and each sample bottle was filled with $320 \mathrm{ml}$. a total of 180 bottles were prepared for shelf life studies; 18 bottles were randomly arranged under refrigerated or ambient room condition while 162 bottles were randomly arranged inside the refrigerator with $-4{ }^{0} \mathrm{C}$ temperature.

\section{Data Gathering Procedure}

A hundred and five trained and consumer-type panelists or judges carried out sensory evaluation and acceptability test of the six treatments of soymilk beverages. They were chosen based on their specific age range, allergy-free, sugar or fructose, and available for complete evaluation of all six samples at one time. The respondents comprised of purposely-selected male and female college faculty members aged between 35 to 55 ; staff aged between 25 to 45 ; farm workers aged 35 to 40 years old; and the college students aged 16 to 21, of the college of Agriculture, Mindanao State University, Marawi City. Each tester was given six coded randomized samples of the unflavored and five different flavored soymilk. A cup of drinking water was offered to cleanse their palate in between sample evaluation in order to minimize sensory carryover/and or fatigue effects. The evaluators provided a nine-point Hedonic scale rating form where 9 was the highest score and 1 was the least score. This was used to test for flavor, texture, and color acceptability. The level to which a product was accepted was expressed as: extremely accepted 
(9), very much accepted (8), moderately accepted (7), slightly accepted (6), neither accepted nor accepted (5) slightly unaccepted (4), moderately unaccepted (3), very much unaccepted (2), extremely unaccepted (1). Extremely accepted to slightly accepted constituted good, while slightly unaccepted to extremely unaccepted constituted poor. Neither accepted nor unaccepted shows that the product was neither good nor bad.

Shelf life of flavored soymilk was methodically and closely monitored using the organoleptic or sensory test. The proponent conducted a precarious visual monitoring, organoleptic testing and evaluation of samples, and recording of data of the storage methods both refrigerated and unrefrigerated samples. Refrigerated samples were monitored in 24-hour interval while unrefrigerated samples were monitored in 5-hour interval until samples were no longer fit for drinking. This procedure was done to measure the products' suitability for human consumption. At least three (3) samples from every treatment or (1) representative from every replication was subjected to the said test each day. Spoiled samples were removed from the shelves.

\section{Statistical Analysis}

The following statistical tools were utilized in this study: Analysis of Variance (ANOVA), T Test for Independent Samples, Duncan Multiple Range Test (DMRT), and Return on Investment (ROI).

\section{Discussion and Findings}

From the data gathered, findings revealed that different treatments of the flavored soymilk have significant differences among one another. The products' overall acceptability revealed that strawberry, banana and melon flavored soymilk ranked moderately acceptable while the unflavored, the mango and soursop flavored soymilk were slightly acceptable. Generally, the product was acceptable and rated as good.

In terms of shelf life stability, the study revealed that among flavored soymilk in refrigerated sample, melon flavored soya obtained the longest averages shelf life of 586 hours or 24 days, while mango flavored soymilk achieved the shortest average shelf life of 248 hours or 10 days. For unrefrigeratedsoymilk under room temperature, unflavored soymilk has as average shelf life of 10 hours and the flavored soymilk such as soursop and banana had an average shelf life of ten hours, while mango flavor has the lowest average shelf life of 8 hours. Also, study shows that the test of difference and interaction between the storage methods and flavored soymilk revealed no significance. Lastly, the average Return on Investment (ROI) of the soymilk production is highly feasible since in every 100 pesos invested, there is an average return of 35.79 pesos.

\section{Conclusion}

Based on the findings of the study, soymilk sensory attribute is greatly related to the method of preparation and storage, right choice of soybean variety, and the accurate measurement of ingredients. Acceptability depends largely on the flavor, texture and color characteristics of the products. Furthermore, the product's shelf life is traceable on the specific storage method using appropriate packaging material and hygienically, scientifically andaesthetically prepared. Thus, to prolong the shelf life of flavored soymilk, it is recommended that the product should be refrigerated. Soybean-based products like soymilk provides profit, specifically refrigerated flavored soymilk; it demonstrates marketable and feasible acceptance in the market.

\section{References}

[1] Amerine, M.A., Panghorn, R.R, and Roessler E.B.(1965). Principles of Sensory Evaluation of Food. The Academic Press., N.Y., p. 597.

[2] Ancheta, Rufina R. (1987). Soybean Processing and Utilization for the Rural Families, Home Economics Division, Bureau of Agricultural Extension, Diliman Quezon City Journal pp 1-3.

[3] Carangal, A.R., L.G. Gonzalez and I.L. Daguman (1961). The Acid Constituents of Some Philippine Fruits. Philip. Agric. 44(10):514-519

[4] Chambers E., Jenkins A. and MCguire B.H. (2006). Flavor Properties of Plain Soymilk. Journal of Sensory Studies 21: 169-70.

[5] Claudio, V., Leocadio C., De Leon S., Jose L. (2001). Food Safety and Sanitation for the Philippine Consumers. Manila, Merriam Webster Co. 
International Journal of Science and Management Studies (IJSMS)

Volume: 02 Issue: 01
January to February 2019
E-ISSN: 2581-5946

www.ijsmsjournal.org

[6] Clinton, MI (1997) Eden Foods 'Soy Beverage Manufacturing Process. Viewed May 10,2015. http://www.madehow.com.

[7] De Leon, Sonia Y., Claudio, Virginia, Chavez, Libia L and Guzman, Matilde P. (1999).Basic Foods for Filipinos. Merriam \& Webster Book Store, Inc. Manila, Philippines.

[8] Delgado Araujo A. J. (2007). Method for preparing a beanless-flavor soymilk and/or okara using carbon dioxide in a state of sublimation. Official Gazette of the United States Patent and Trademark Office Patents. San Blas, Quito, Equador, U.S.A.

[9] Faber ,Birren. (1963). Color and Human Appetite. Food Tech. 17 (5-8), p. 553.

[10] Foster, D. (1956). Psychological Aspects of Food Colors from the Consumers Standpoint, Mimeo $\quad$ Report $14 \quad$ PP. US Testing Company, Hoboben, New Jersey.

[11] Gajc J., Skapski H. (1991). Wplywfazydorjzalosciowocowczterechodmiancikininaichplonoraz wartoscbiologiczna.Biul, Warzywn. 37, 119128.

[12] Gatchalian, Miraflora M. (1981). Sensory Evaluation Methods with Statistical Analysis for Research,Product Development and Quality Control.Merriam \&Webster Bookstore, Inc., Manila Philippines.

[13] Gatchalian, Miraflora M. \& De Leon, Sonia Y. (1992).Introduction to Food Technology.Merriam \& Webster Bookstore, Inc., Manila Philippines.

[14] Gatchalian, M.M. (1986) Status and Prospects of Food Processing in the Philippines.Phil Journal of Food Science and Technology. 10 (1, 2) pp. 21-31."'

[15] Grooms, Dal. (1997). “Organic Foods Move Into Mainstream, Say lowa Buyers.” In lowa Farm ～～Bureau Spokesman.lowa Farm Bureau Federation, West Des Moines, IA.

[16] Gyesley, S.W. (1991). Total System Approach to Predict Shelf Life of Packaged Foods. ASTM Internatonal: Food Packaging Technology, pp. 46-50. Viewed November 29, 2015.https://en.m.wikipedia

[17] Ha, E. Y. W., Morr, C. V. \&Seo, A. (1992). IsoflavoneAglucones and Volatile Organic Compounds in Soybeans Effects of Soaking Treatments. Journal of Food Science, 57, 414-436.

[18] Hajirostamloo, B. (2009). World Academy of Science, Engineering and Technology.Comparison of Nuritional and Chemical Parameters of Soymilk and Cow Milk.Journal pp. 436-438.

[19] Hasler, C.M. (1998). Functional Foods: Their Role in Disease Prevention and Health Promotion Technology 52:63-70.

[20] Hayta, M., Alpaslan, M. and Cakmakli U. (2003). Physicochemical and Sensory Properties of Soymilk Incorporated Bulgur, Journal Food of Science 68: 2800-2803.

[21] Hisona, Kenneth A. (March 2015). A Feasibility Study on Small Scale Ube Soya Milk Bar Processing and Manufacturing.Undergraduate Feasibility Study.Central Mindanao University, Musuan, Bukidnon.

[22] Huo J.W., R.C. Yu and C.C. Chou (2000). Changes in Some Components of Soymilk during Fermentation with Bifido-Bacteria. Food Res. Int. 33: 393-7.

[23] Kramer, A. and Twig B.A. (1973). Quality Control for the Food Industry.Vol.2 P 157 AVI Wesportcon.

[24] Kwok, K., Basker, D., \&Niranjan, K. (2000). Kinetics of Sensory Quality Changes in Soymilk During Thermal Processing, By Parametric and Non-Parametric Data Analyses. J Sci. Food and Agric. 80(5):595.

[25] Lawless H.T. \&Heymann, H. (1999). Sensory Evaluation of food: principles and Practices. Gaithersburg: Aspen, p. 827.

[26] Lee, Jill. (1997). “New Soybeans Fill Tofu Niche.” Agricultural Research 45(11):13.

[27] Luna, Ma. Veritas. (2005). Guzman's Introduction to Food Preparation. Meriam \& Webster Bookstore, Inc., Manila Philippines.

[28] Ludvigsen, Hannie K. (2011). Palsgaard Technical Paper, Manufacturing Delicious Soy Milk, pp. 1-5.

[29] Lv, Y.C., Song, H.L., Ll, X., Wu, L.\&Guo, S. T. (2011). Influence of Blanching and Grinding Process with Hot Water on Beany and Non-Beany Flavor in Soy Milk. Journal of Food Science,76, 20-25.North Dakota Agricultural Statistics Service. Various years.North Dakota Agricultural Statistics. North Dakota Statistics Service, North Dakota State University, and U.S. Department of Agriculture, Fargo.

[30] Macarandan, Christy Jane H. (2011) A Feasibility Study of Small Scale Soy Milk Processing and C Marketing, Undergraduate Feasibility Study. Central Mindanao University, Musuan, Bukidnon.

[31] Masuda, T. \& Goldsmith, P.D. (2009). World Soybean Production: Area Harvested Yield and Long Term Projections. International Food and Agribusiness Management Reviw, 12(4), 143-162. 
International Journal of Science and Management Studies (IJSMS)

Volume: 02 Issue: 01
January to February 2019
E-ISSN: 2581-5946

www.ijsmsjournal.org

[32] Matsuura, M. Obata, A., Fukushima, D. (1989). Objectionable flavor of soymilk developed during the soaking of soybeans and its control. J. Food Sci. 54:602

[33] Meilgaard, M., Caviled, and Carr B.T. (2007). Sensory Evaluation Techniques $4^{\text {th }}$ Ed.CRC Press. Inc. ISBN 0849338395, 9780849338397.

[34] Minim, M, V. P. R. (2006).AnaliseSensorial:Estudo Com. Consumidores. Vicosa: UFV, p.225

[35] Min, S., Yu, Y., Yoo, S. \& Martin, S. S. (2005). Effect of Soybean Varieties and Growing Locations on the Flavor of Soymilk.Journal of Food Science. pp. 1-7.

[36] Mondragon- Bernal G.L. (2004) DesenVolvimento de Uma bebidFermentada de JoJa Contend Agents Preboiotics e Probiotics Campinas: Food Engineering Faculty Univ. Campus, p. 192.

[37] Murtl, T.W. , G. Lamberet, C Bonillane, M.T. Cesmuzeaud, and M. Landon (1993). Croissance des Lactobacillus dantstextrait de joja. Sciences des Alimenr 13 (3): 491-500

[38] Paine, F. A. (1962). Fundamentals of Packaging. Blackie and Sen Ltd., London.

[39] Pino, J. A., \&Mesa, J., Munoz, Y., Marti, M. P. \&Marbot, R. (2005).Volatile components from mango (Mangiferaindica L.) cultivars.J.Agric. Food Chem. 53, 2213-2223.

[40] Qui, L.-J.\& Chang, R.-Z (2010).The Origin and History of Soybean. In Singh, G. (eds.) Soybean: $\quad$ Botany, Prodution and Uses (pp. 1-23). Cabi Publishing, Wallingford 0x10 8de, Oxon, UK: Cabi Publishing Co.

[41] Reilly, J.K., Lanou, A.J., Barnard N.D., Seidl K. and Green A.A. (2006). Acceptability of Soymilk as a Calcium-rich Beverage in Elementary School Children. Journal of the American Medical Association 106:590-593.

[42] Rosenthal, Amauri; Deliza, Rosires; Cabral, Lourdes M. C.; Cabral, Lair C.; Farias, Carlos A.A.; Domingues, Aline M. (2003). Effect of Enzymatic Treatment and Filtration on Sensory Characteristics and Physical Stability of Soymilk.Food Control.P. 14.

[43] Steinkraus, Keith H., David, I.T., Ramos, L.J. and Banzon, Julian (1988). Development of Flavored Soymilks and Soy/ Coconut Milks for the Philippines Market.Journal of the College of Angriculture and central Experiment Station U.P. Vol. Lll. No. 5

[44] Stone, H., and Sidel, J.L. (1993).Sensory Evaluation Practices.@nd Edition. Academic Press, Inc. $\quad$ San Diego, California. 338pp.

[45] Ugwu, D.S., \&Ugwu, H.C. (2010).Soybean Production, Processing and Marketing in Nigeria.Journal of Applied Sciences and Deelopment, 1(1). 45-61(3): 187

[46] Sonido, Divina G. Chavez, Libia L. and De Leon Sonia Y. (2009).Practical Food Preservation and Processing.National Book Store, Manila, Philippines.

[47] Soriano, Nora Narvaez (2010). A Guide to Food Selection, Preparation and Preservation.Rex Book Store, Manila, Philippines.

[48] Soroka, W. (2002).Fundamentals of Packaging Technology. ISBN 1-930268-25-4

[49] Shung-Tang, G., Ono, T. Mikami, M. (1997).Incorporation of Soymilk Lipid into Protein Coagulum by Addition of Calcium Chloride. J Agric. Food Chem. 45:4601-4605

[50] Shurtleff, W and Aoyagi, A. (1983).Soymilk Industry and Market.Soy foods Center, Lafayette, Cal. CA.

[51] Shutt, D.A; Cox, R.L. (1972).Steroid and Phyto-estrogens binding to sheep Uterine Receptors Invitro.

[52] Taylor, R.D. \& Koo, W. W. (2011). Outlook of the U.S. and World Corn and Soybean Industries, $\quad$ 2010-2020. Agribusiness \& Applied Economics Report Department of Agribusiness and Applied Economics, North Dakota State University, Department of Agribusiness and Applied Economics, North Dakota State Unversity; Fargo; USA

[53] Tiersky, Arthur (2010). Silk FAQs Milk Subtitute: Soy, Rice and Almond Drinks. Silk FAQs viewed June $20,2015$. https://.silksoymilk.com/content/faq Articles/Nutrition/Healthy-eating/6 health bebefits of soymilk.http://www.fitday.com/fitness USDA Nutrient Database for Standard reference. www.soya.nutrition

[54] Villegas B. Carbonell 1., Costelle.(2008). Acceptability of Milk and Soymilk Vanilla Beverages, Demographic Consumption Frequency and Sensory Aspect.

[55] Ylagan, M.M. (1961). Ascorbic Acid Contents of some Philippines fruits. Philip. Agric. 44 (9):477-478

[56] Zadernowski R., Oszianski J. (1994). Wybranezagadniena z przetworstwaowocow I warzyw.Wyd ART Olsztyn 